University of Nebraska - Lincoln

DigitalCommons@University of Nebraska - Lincoln

Faculty Publications: Department of Teaching, Department of Teaching, Learning and Teacher Learning and Teacher Education

6-3-2021

Disrupting Evasion Pedagogies

Kara Mitchell Viesca

Tricia Gray

Follow this and additional works at: https://digitalcommons.unl.edu/teachlearnfacpub

Part of the Curriculum and Instruction Commons, and the Teacher Education and Professional

Development Commons

This Article is brought to you for free and open access by the Department of Teaching, Learning and Teacher Education at DigitalCommons@University of Nebraska - Lincoln. It has been accepted for inclusion in Faculty Publications: Department of Teaching, Learning and Teacher Education by an authorized administrator of DigitalCommons@University of Nebraska - Lincoln. 


\title{
Disrupting Evasion Pedagogies
}

\author{
Kara Mitchell Viesca and Tricia Gray \\ University of Nebraska-Lincoln \\ Correspondence - Kara Mitchell Viesca kara.viesca@unl.edu
}

\begin{abstract}
As we have researched in schools and reflected on our own teaching, we have come to recognize the lie and our untruthfulness that permeates many of our cultural scripts (Gutierrez et al., 1995) and practices as teachers. It is within these cultural scripts and practices that inequity is perpetuated and humanizing learning evaded. Thus, what we term evasion pedagogies, serve to sustain the status quo and are powerful tools to maintain oppressive projects like white supremacy, heteronormativity, gender binaries, patriarchy, ableism, classism, and linguicism. In this piece, we examine the notion of evasion pedagogies as a powerful lie in practice that needs to be disrupted in teaching and learning across grade levels and contexts. Then, we draw on decades of research to illustrate how existing scholarship offers meaningful opportunities to disrupt evasion pedagogies by focusing on humanization.
\end{abstract}

Keywords: Critical theory, equity, humanizing pedagogies, racial justice

In August 2018, Jonathan Rosa, a linguistic anthropologist tweeted, "So excited about a piece I am working on regarding Trump and the alleged post-truth moment we currently inhabit titled, 'We have never been truthful." The statement, "we have never been truthful" struck us with incredible force. Months later at AERA in Toronto (2019),

Published in Journal of Language, Identity \& Education 20:3 (2021), pp 213-220.

doi:10.1080/15348458.2021.1893173

Copyright (C) 2021 Taylor \& Francis Group, LLC. Used by permission.

Published 3 June 2021. 
we were pushed to further consider our untruthfulness with a statement and question from David Stovall as he participated on a panel regarding navigating identities as critical-scholar-educator-activists, "We are continually being lied to. How do you disrupt the lie?" The lie and our history of never being truthful are as American as pledging "liberty and justice for all" on the soil stolen from Native Americans through genocide while Tribal sovereignty is still largely denied, issues around missing and murdered Indigenous women continue to expand, and police brutality remains. It is the lie told when "All men are created equal" was written into the Declaration of Independence while enslaved people from Africa were counted as $3 / 5$ a person. The lie and our history of never being truthful is an important part of white supremacy and its maintenance, which race scholars and educators have clearly documented (e.g., Kendi, 2017; Matias, 2016). As we have researched in schools and reflected on our own teaching, we have come to recognize the lie and our untruthfulness that permeates many of our cultural scripts (Gutierrez et al., 1995) and practices as teachers. It is within these cultural scripts and practices that inequity is perpetuated and humanizing learning evaded.

Thus, what we term evasion pedagogies, serve to sustain the status quo and are powerful tools to maintain oppressive projects like white supremacy, heteronormativity, gender binaries, patriarchy, ableism, classism, and linguicism. For us, two White female critical scholars committed to racial justice, this work of identifying the lies and untruthfulness in our own work and striving to disrupt it is made possible by the decades of impactful scholarship from Indigenous scholars, Scholars of Color, and other critical scholars (e.g., Alim et al., 2020; Bartolomé, 1994; Freire, 1994; Gay, 2002; Ladson-Billings, 1995; McCarty \& Lee, 2014; Paris, 2012; Villegas \& Lucas, 2007). Existing scholarship provides methods of disrupting evasion pedagogies that can deepen our understanding and ability to engage in humanizing pedagogies or pedagogies grounded in the truth of our complex realities, histories, and relationships. In this piece, we examine the notion of evasion pedagogies as a powerful lie in practice that needs to be disrupted in teaching and learning across grade levels and contexts. Then, we draw on decades of research to illustrate how existing scholarship offers meaningful opportunities to disrupt evasion pedagogies by focusing on humanization. 


\section{Evasion pedagogies}

Pedagogy is an expansive concept that typically focuses on the complex interplay of teaching and learning theory, method, orientation, and practice. At its core, pedagogy is the project of teaching and learning. Understood as such, pedagogy can be conceived as occurring in a variety of spaces via myriad interactions with diverse actors (not just people labeled teachers and students). However, what is often operationalized in classrooms as teaching is actually monitoring or surveillance and performances of learning are frequently limited to compliance. Such cultural scripts and performances of teaching and learning do not appear to be about teaching or learning at all. Yet, when those cultural scripts are performed, students do learn and are taught to operate as obedient actors under authoritarian control, not to think for themselves, but to regurgitate the ideas and work of others.

In 2017, Annamma et al. argued for the conceptualization of colorevasiveness (in contrast to the typically used term in race scholarship, "colorblind") and described evasion as, "about avoidance or escape, not about explicitly creating solutions to problems." (p. 156) Annamma and colleagues suggested that what is typically labeled a "colorblind" ideology is actually overtly and openly color-evasiveness or an effort to evade creating solutions to problems centered on race that we face in school and society. Along those same lines, we suggest that evasion pedagogies ${ }^{1}$ serve the same purpose: to evade solving the fundamental problem of inequity in our schools and society through the project of teaching and learning. Thus, evasion pedagogies serve to sustain the status quo and are powerful tools to maintain oppressive projects, often under the cover of the institution of schooling. Like with color-evasiveness, identifying evasion pedagogies creates the impetus for recognizing power and responsibility-to move beyond avoidance or escape.

Evasion pedagogies are operationalized through a variety of approaches, some discussed below. Specifically, we focus on majoritarian stories and cultural scripts, the practice of emphasizing image over

1. Zavarzadeh (1992) discusses "parapedagogy" as "evasion" as a "bracketing" of the learner's whole self. Our use of the term is distinct in that we focus on the evasion of equity through pedagogy. 
substance, and the power of boundaries and limited relationships in creating the context for evasion pedagogies to thrive. This work builds on and extends that of a wide range of scholars who have identified and problematized various forms of oppression in school and society. By naming and describing aspects of evasion pedagogies, we strive to take responsibility for our own roles in the lie(s) we tell and perform through our pedagogies and invite other educators and education researchers to do the same. We think it is possible to move beyond avoidance or escape, to disrupt the willful ignorance and lack of responsibility, and to recognize and take up our power to move broadly towards equity.

\section{Majoritarian stories and cultural scripts}

A conceptual tool offered by critical race theory (e.g., Howard \& Navarro, 2016; Ladson-Billings \& Tate, 1995; Yosso, 2006), is the concept of majoritarian stories. The overarching tenets of critical race theory centralize race; challenge meritocracy, objectivity, neutrality, and ahistoricism; emphasize experiential knowledge; and support interdisciplinarity (Matsuda et al., 1993). Critical race scholars have recognized how majoritarian stories typically stand in contrast to these tenets and thus need to be challenged. B. J. Love (2004) defines majoritarian stories as "The description of events as told by members of dominant/majority groups, accompanied by values and beliefs that justify the actions taken by dominants to insure their dominant position" (p. 228). The outcome of majoritarian stories, as illustrated by Love, is oppression.

In education research and practice, some common majoritarian stories have been identified and problematized, such as "there is no story about race" (Bonilla-Silva, 2009; Cochran-Smith, 1995; Pollack, 2004), "difference is deficit" (Delpit, 1995; Oakes, 1985; Valencia, 2010), "meritocracy is valid" (Guinier, 2016), and in the education of multilingual students, "English is all that matters" (Abedi, 2004; Mitchell, 2013). These stories are detrimental to student learning and are often perpetuated through pedagogical practices that may seem harmless and even well intentioned. Students learn who matters in which contexts; which knowledge and language are considered "academic" and thus important (e.g., Abedi, 2004; Mitchell, 2013); which bodies 
are criminal, trustworthy, acceptable, etc. (e.g., Castañeda, 2006; De Genova, 2006; Santa Ana, 2002); whose ways of being are appropriate and good (and whose are not) (e.g., Bondy, 2015; Shalaby, 2017); and whose agency holds power within academic spaces (Moll et al., 1992; Yosso, 2005). Majoritarian stories are a major part of what is taught and what students learn in school. However, for the most part, these stories are unexamined in pedagogies. And by leaving them unexamined, educators evade disrupting the negative messages students receive, embracing the variety of diversities students bring to the classroom as productive, and affirming those diversities as important.

These evasions can be found in how cultural scripts that exist around teaching and learning are sustained. To be certain, majoritarian stories teach teachers a great deal as well. Teachers learn through the standardized evaluation policies and procedures what it means "to teach." To teach well means to police students' bodies and minds to be "in control," and to learn well means to be quiet and still and to comply with the teachers' requests or demands. To teach well means to transmit a prescribed monolithic set of knowledge, to manage classroom activities efficiently, and stay on "pace" with a predetermined timeline, to recite a script "with fidelity," to monitor that all students meet the same outcomes. In short, teaching is a performance of surveillance, and learning, in response, is a performance of compliance. It is important to note that teachers do not work in isolation and their/our pedagogies are influenced by the work of administrators, policymakers, and community members, but we focus on teachers across this piece as they/we are the actors closest to the classroom pedagogies.

\section{Image over substance}

Kendi (2019) argues that in racial justice work, people can focus on advocacy that makes them feel better (or antiracist), but which does not create or sustain any lasting change. This is a feature of evasion pedagogies and an element of that pedagogical project ensuring a commitment to image over substance. The lies and untruths remain strong when the predominantly White teaching force (we included) are more focused on looking like "allies" than actually being anti-racist accomplices (B. L. Love, 2019). This can happen as easily as a White 
teacher telling a Colleague of Color that they value their perspective on issues of inequity while also talking over that colleague to be sure their perspective is heard.

To some extent an evasion pedagogy that emphasizes image over substance is a comfortable place to claim to have an assets-based perspective of students and families while discussing their needs and the challenge it is to work with them. To truly see and draw upon students' and families' strengths, the focus should be on the opportunities and abilities they bring to the learning community instead of the deficits that are perceived when measured against a common norm (e.g., Hopewell \& Escamilla, 2014). Assets-based research articles would not label students based on their real or perceived deficiencies and the purpose of educational projects would not be centered on pathologizing such deficits. The tendency is to focus on learners' needs and gaps rather than on their strengths, assets, and abilities through language practices as well as pedagogical and research projects (Gutiérrez \& Orellana, 2006).

Further, many language educators/teacher educators (we included) claim to value democracy, pluralism, multilingualism, and multiculturalism. Yet we most often teach in one language and share the ideas of our expertise through readings and assignments of our design and choosing (that most often reflect our own ideologies and research paradigm). We present an image that matches what we think we should be or are, but the substance of our practices presents a counter-narrative to that image. Or in other words, a lie-a lie our students see and that fosters a distance from us as well as distrust in our work and the institutions we maintain. James Baldwin famously said, "I can't believe what you say because I see what you do." It is easier to engage in an evasion pedagogy and focus on the image we hold of ourselves as teachers and researchers versus the impact of our actual practices, language use, and scholarship.

\section{Relationships}

An evasion pedagogy is a pedagogy that embraces and promotes boundaries, particularly for their ability to assert control and act as oppressive barriers. However, more and more work across varying disciplines is promoting the blurring of traditional boundaries to embrace 
the intense complexities that constitute human life, history, and learning (Anzaldúa, 1987). For instance, the work of Ofelia Garcia (2009) around translanguaging has pushed the field to consider the complex realities of multilingualism and the blurred lines between named languages and the expansive linguistic repertoire of multilingual people. In blurring these boundaries, new pedagogical and ideological possibilities have emerged that substantively embrace multilingual complexities and successfully tear down multiple boundaries (e.g., Kiramba, 2019).

In schools and classrooms, boundaries exist as rules, policies, cultural practices, and ideological tools. In many classrooms and schools, these boundaries are used as methods of social control for both teachers and students. An evasion pedagogy evades the opportunities to teach students to be responsible members of a learning community who are accountable to one another, to make careful choices and to be trusted enough to be left to learn without constant surveillance. In fact, an evasion pedagogy embraces boundaries for how such boundaries create justifications for complicity with oppressive practices without having to take personal responsibility for engaging in oppressive work. By evading this responsibility, teaching can continue to be performed as monitoring and learning as compliance because of the curriculum, the rules the district/university has put into place or the expectation that all teach the same things at the same time across grade levels/departments.

To be certain, these are real challenges with which teachers grapple daily, but the boundaries put around teaching and learning practices with students are often boundaries that help evade the opportunities (and responsibility) to truly teach and learn with students. Further, those boundaries are often more malleable than static. The boundaries are themselves a lie that enforces a segmentation of people and practices that does not reflect the reality of human interaction and communication. When the focus is on maintaining unnecessary boundaries, there is a commitment to perpetuating the lie and evading the possibilities of true connections across ideas and people.

A core aspect of authentic learning is strong relationships-between students and teachers as well as among students themselves (e.g., Peguero \& Bondy, 2011). However, an evasion pedagogy embraces the boundaries described above and centers punishment and 
discipline over interaction and understanding. It is another lie. Evasion pedagogies do not teach the values of creativity, democracy, pluralism, and multiculturalism. Nor do they foster a culture of compassionate belonging. Rather, evasion pedagogies promote hierarchical relationships grounded in control, secrecy, surveillance, and compliance (Foucault, 1977). Further, obedience and submission are taught while messages are sent that diminish the humanity of the person(s) not being offered a space for their creativity and expression. Moreover, opportunities for students to learn authentically from one another are thwarted when the teacher is positioned as the only meaningful knower in the classroom.

To be certain, human interactions are complex, messy, and at times, destructive. The reality is that humans are all prone to mistake-making as well as self-centeredness. Yet in the context of teaching and learning, there is so much possibility when those challenging realities are acknowledged and coalitions are created to co-construct solutions to various issues and problems. An evasion pedagogy does not create space for such interactions or relationships. Rather, an evasion pedagogy focuses on punishing poor behavior or mistakes rather than creating the context to learn from them. It deals in the traditional practices of authoritarian decision-making versus democratic problem-solving. Teachers are not allowed to admit fault or flaws in evasion pedagogies and students are often left bewildered, confused, and resentful regarding punishments received. In the end, an evasion pedagogy dehumanizes through straining relationships due to their focus on segmentations, boundaries, monitoring, control, and punishment versus collaborative learning, improvement, and growth.

\section{Disrupting evasion pedagogies}

There is a strong and deep intellectual tradition led by critical scholars, mainly Scholars of Color and Indigenous Scholars, who have long provided a pathway for us to pedagogically disrupt the untruths and lies of evasion pedagogies, particularly via the implementation of culturally and linguistically responsive/relevant/sustaining/revitalizing, critical and sociocultural pedagogies (e.g., Alim et al., 2020; Bartolomé, 1994; Freire, 1994; Gay, 2002; Ladson-Billings, 1995; McCarty 
\& Lee, 2014; Paris, 2012; Villegas \& Lucas, 2007). What these and many other scholars have long argued for are humanizing pedagogies-pedagogies that center learning as the goal, tell counter-stories that disrupt the oppression caused by majoritarian stories, focus on substance over the image, break down unnecessary boundaries and are fundamentally grounded in authentic relationships. To do this work is to engage in humanizing pedagogies.

There are myriad ways to disrupt evasion pedagogies just as there is a variety of ways to enact them. We have identified some practices that have helped us in our efforts to disrupt evasion pedagogies and engage in more humanizing practices. Specifically, we have focused on learners, community, and inquiry in our practice. Our efforts are not new (e.g., Alim et al., 2020; Freire, 1994; Ladson-Billings, 1995), rather our own attempt to disrupt the lie.

\section{Learners}

We value learning and learners as having agency, working best in collaboration where there is also space for leadership so that learners can take meaningful ownership over their own learning. While we have seen the value of this in our work with teachers (empirical work forthcoming), we believe there is value in efforts to disrupt evasion pedagogies by creating learning contexts where all learners, regardless of age and English proficiency level, have agency, can work in meaningful collaboration and take leadership over their own learning (and at times that of others). In fact, we have seen this in practice in a 5 th grade classroom with a high percentage of students labeled "English learner" and on Individualized Education Programs (indicating they had identified learning disabilities) (Viesca et al., 2019). Students wrote lesson plans to lead each other through book studies of books they selected to read in collaboration with peers who shared responsibility for the learning and teaching of their selected book. This teacher viewed her students and helped her students view each other, as capable. She saw the learning assets they brought to the classroom and created a space for those assets to be built upon and expanded. In the same study we also observed a primary teacher in England teaching a scripted, required phonics lesson from the national curriculum. However, the pedagogy she implemented to meet policy requirements 
was deeply responsive to the students in the classroom, incredibly engaging, and meaningfully created the context for agency, leadership, and collaboration for all of the learners.

It must be noted, in the context of discussing agency, many teachers feel like their own is limited, as might have been the context for the English teacher. However, as these examples illustrate, meaningful possibilities exist when educators examine their realm of power and influence and take responsibility for humanizing pedagogies that center learning and the learners. Sometimes there are more opportunities for such practices than are obvious by simply looking beyond what has always been done to seeing what is truly possible.

Creating the context for learners to take agency and leadership over their learning and to work in collaboration with their peers is to disrupt evasion pedagogies. Disrupting the cultural scripts that suggest teaching be performed as monitoring and learning as compliance is humanizing. Embracing the messy substance of learning over the reductive images of it and creating new possibilities for relationships and the disruption of unhelpful boundaries is freeing. In fact, to focus on learner agency, leadership and collaboration are to complicate the "student-teacher contradiction" as Freire (1994) suggests, "The teacher is no longer merely the-one-who-teaches, but one who is himself taught in dialogue with students, who in turn while being taught also teach" (p. 80). By centering learners through agency, leadership, and collaboration, teachers can meaningfully learn as well.

\section{Community}

The success of a pedagogy centered on learner agency, leadership, and collaboration is situated in the context of a strong learning community. Our current understanding of strong community is influenced by Indigenous scholarship and scholars (e.g., Kimmerer, 2013; Lomawaima \& McCarty, 2002; Simpson, 2017) and thus grounded in principles of self-actualization, reciprocity, and accountability. These principles are intricately connected and in combination generate substantive possibilities for transformative equity-based learning to occur. Self-actualization is important individually as well as collectively for it is how within strong learning communities all can work toward becoming and bringing their truest selves to the learning space 
while also creating that possibility for other members of the learning community. Through self-actualization, all of the dynamic identities of the learners in a community are affirmed in the learning space. Clearly, self-actualization for all can only successfully occur in reciprocity where any one person's self-actualization cannot come at the cost of that of another. Further, accountability to the principles of selfactualization is necessary as communities are situated in colonial, white supremacist, ableist, heteropatriarchies that have been established to limit self-actualization in very tangible ways. Through proactively and continually learning about and with one another, learners are able to benefit from the varied life experiences, expertise, and perspectives of the members of the classroom community in incredibly productive ways.

Learners in this kind of classroom community have reported that they got to know each other better, learn from their peers in a courageous space where risk-taking was fundamental and even do challenging work that they have shied away from in other learning spaces. Many have stated that they came to regard themselves as democratic citizens for the first time in their lives. Creating a strong learning community is more than just doing introductions and icebreakers on the first day. It is even more than co-constructing norms for the class. The kind of learning community that disrupts evasion pedagogies is co-constructed and reconstructed over time through pedagogical approaches and curriculum that humanize each member of the learning community as individually important and collectively valuable.

\section{Inquiry}

The principles discussed above regarding learners and community cannot be meaningfully put into practice with traditional pedagogies that center a transmission model of teaching and learning-what Freire (1994) calls "banking education." For learners to truly exercise agentic leadership as well as work in meaningful collaboration while they engage in a community where self-actualization occurs in reciprocity and with accountability, the engagement with new ideas needs to fundamentally be through an inquiry approach. And while there is substantial evidence of the benefit to inquiry-based pedagogies (e.g., Johnson et al., 2016; Manzo et al., 2011; Santau et al., 2011), it is still 
often a missing component of learning opportunities for many teachers as well as K-12 students.

Freire's (1994) "problem posing education" is instructive in constructing learning experiences grounded in the inquiry. Students bring with them a diverse range of experiences on which to draw in posing questions for dialogical investigation, and by engaging in these investigations together, critical thinking skills like identification of the problem, deliberation, and making connections among diverse perspectives are employed and grown. Importantly, the inquiry is oriented toward solving problems that are relevant to students' lives. As students develop their ideas about a problem, they describe the world through their own lenses and in their own words; through dialogue with others, they learn to understand through others' experiences as well.

\section{Moving forward}

At the time of finalizing this manuscript, the COVID-19 global pandemic is still in full swing. Vaccines are starting to be distributed and hope for a return to safe social engagement in the coming months and years is growing. In this context, massive opportunities exist to create a new normal, one that is about humanizing pedagogies versus evading ones. Grounded in the long-standing scholarship and wisdom of Indigenous Scholars, Scholars of Color and critical scholars (e.g., Kimmerer, 2013; Ladson-Billings, 1995; Simpson, 2017), educators can coconstruct a new normal that disrupts the lie, the untruthfulness that has been maintained through evasion pedagogies. Learning spaces can be co-constructed by teachers and learners that are grounded in the agency, leadership, collaboration, self-actualization, reciprocity, accountability, and inquiry. However, various issues of power and privilege must be accounted for to move away from the kinds of evasion tactics that have typically been in practice. Disrupting evasion pedagogies means creating teaching and learning spaces where stated goals, messages, and values actually match actions and impacts. To do this, we encourage all educators and educational researchers (including us) to engage in investigations of their own practices to find and disrupt evasion pedagogies where necessary. For, in the end, moving away from the robotic cultural scripts that operationalize teaching 
as monitoring and learning as compliance, efforts to disrupt evasion pedagogies can become a source for extensive humanization to be advanced, even our own.

\section{References}

Abedi, J. (2004). The No Child Left Behind Act and English language learners: Assessment and accountability issues. Educational Researcher, 33(1), 4-14. https://doi.org/10.3102/0013189X033001004

Alim, H. S., Paris, D., \& Wong, S. P. (2020). Culturally sustaining pedagogy: A critical framework for centering communities. In N. S. Nasir, C. D. Lee, R. Pea, \& M. M. De Royston (Eds.), Handbook of the cultural foundations of learning (pp. 261-276). Routledge.

Annamma, S., Jackson, D. D., \& Morrison, D. (2017). Conceptualizing colorevasiveness: Using dis/ability critical race theory to expand a color-blind racial ideology in education and society. Race Ethnicity and Education, 20(2), 147162. https://doi.org/10.1080/13613324.2016.1248837

Anzaldúa, G. (1987). Borderlands/la frontera: The new mestiza. Aunt Lute Books.

Bartolomé, L. I. (1994). Beyond the methods fetish: Toward a humanizing pedagogy. Harvard Educational Review, 64(2), 173-194. https://doi. org/10.17763/haer.64.2.58q5m5744t325730

Bondy, J. (2015). Hybrid citizenship: Latina youth and the politics of belonging. The High School Journal, 98(4), 353-373. https://doi.org/10.1353/ hsj.2015.0012

Bonilla-Silva, E. (2009). Racism without racists: Color-blind racism and the persistence of racial inequality in America. Rowman \& Littlefield.

Castañeda, A. (2006). Roads to citizenship: Mexican migrants in the United States. In S. Oboler (Ed.), Latinos and citizenship: The dilemma of belonging (pp. 143-166). Palgrave Macmillan.

Cochran-Smith, M. (1995). Color blindness and basket making are not the answers: Confronting the dilemmas of race, culture, and language diversity in teacher education. American Educational Research Journal, 32(3), 493-522. https://doi.org/10.2307/1163321

De Genova, N. (2006). The legal production of Mexican/migrant "illegality." In S. Oboler (Ed.), Latinos and citizenship: The dilemma of belonging (pp. 61-90). Palgrave Macmillan.

Delpit, L. (1995). Other people's children: Cultural conflict in the classroom. W. W. Norton \& Co., Inc.

Foucault, M. (1977). Discipline and punish: The birth of the prison. Random House. Freire, P. (1994). Pedagogy of the oppressed. Continuum.

Garcia, O. (2009). Bilingual education in the 21st century. Wiley and Sons. 
Gay, G. (2002). Preparing for culturally responsive teaching. Journal of Teacher Education, 53(2), 106-116. https://doi.org/10.1177/0022487102053002003

Guinier, L. (2016). The tyranny of the meritocracy: Democratizing higher education in America. Beacon.

Gutiérrez, K., \& Orellana, M. F. (2006). The "problem" of English learners: Constructing genres of difference. Research in the Teaching of English, 4O(4), 502-507. https://www.jstor.org/stable/40171712

Gutierrez, K., Rymes, B., \& Larson, J. (1995). Script, counterscript, and underlife in the classroom: James Brown versus Brown v. Board of Education. Harvard Educational Review, 65(3), 445-471. https://doi.org/10.17763/ haer.65.3.r16146n25h4mh384

Hopewell, S., \& Escamilla, K. (2014). Struggling reader or emerging biliterate student? Evaluating the criteria for labeling emerging bilingual students as low achieving. Journal of Literacy Research, 46(1), 68-89. https://doi. org/10.1177/1086296X13504869

Howard, T., \& Navarro, O. (2016). Critical race theory 20 years later: Where do we go from here? Urban Education, 51 (3), 253-273. https://doi. org/10.1177/0042085915622541

Johnson, C. C., Bolshakova, V. L. J., \& Waldron, T. (2016). When good intentions and reality meet: Large-scale reform of science teaching in urban schools with predominantly Latino ELL students. Urban Education, 51(5), 476-513. https:// doi.org/10.1177/0042085914543114

Kendi, I. X. (2017). Stamped from the beginning: The definitive history of racist ideas in America. Bold Type Books.

Kendi, I. X. (2019). How to be an antiracist. One World.

Kimmerer, R. (2013). Braiding sweetgrass: Indigenous wisdom, scientific knowledge and the teachings of plants. Milkweed Editions.

Kiramba, L. K. (2019). Heteroglossic practices in a multilingual science classroom. International Journal of Bilingual Education and Bilingualism, 22(4), 445-458. https://doi.org/10.1080/13670050.2016.1267695

Ladson-Billings, G. (1995). Toward a theory of culturally relevant pedagogy. American Educational Research Journal, 32 (3), 465-491. https://doi. org/10.3102/00028312032003465

Ladson-Billings, G., \& Tate, W. (1995). Toward a critical race theory of education. Teachers College Record, 97(1), 47-68. https://doi. org/10.4324/9781315709796-2

Lomawaima, K. T., \& McCarty, T. L. (2002). When tribal sovereignty challenges democracy: American Indian education and the democratic ideal. American Educational Research Journal, 39(2), 279-305. https://doi. org/10.3102/00028312039002279

Love, B. J. (2004). Brown plus 50 counter-storytelling: A critical race theory analysis of the "majoritarian achievement gap" story. Equity \& Excellence in Education, 37(3), 227-246. https://doi.org/10.1080/10665680490491597 
Love, B. L. (2019). We want to do more than survive: Abolitionist teaching and the pursuit of educational freedom. Beacon Press.

Manzo, R. D., Cruz, L., Faltis, C., \& De La Torre, A. (2011). Professional development of secondary science teachers of English learners in immigrant communities. Association of Mexican American Educators Journal, 5(1), 41-48. https://amaejournal.utsa.edu/index.php/AMAE/article/view/9o

Matias, C. (2016). Feeling White: Whiteness, emotionality, and education. Sense Publishers.

Matsuda, M., Lawrence, C., Delgado, R., \& Crenshaw, K. W. (1993). Words that wound: Critical race theory, assaultive speech and the First Amendment. Westview Press.

McCarty, T. L., \& Lee, T. S. (2014). Critical culturally sustaining/revitalizing pedagogy and Indigenous education sovereignty. Harvard Educational Review, 84(1), 101-136. https://doi.org/10.17763/haer.84.1.983746nl5pj34216

Mitchell, K. (2013). Race, difference, meritocracy, and English: Majoritarian stories in the education of secondary multilingual learners. Race Ethnicity and Education, 16(3), 339-364. https://doi.org/10.1080/13613324.2011.645569

Moll, L. C., Amanti, C., Neff, D., \& Gonzalez, N. (1992). Funds of knowledge for teaching: Using a qualitative approach to connect homes and classrooms. Theory into Practice, 31(2), 132-141. https://doi. org/10.1080/00405849209543534

Oakes, J. (1985). Keeping track: How schools structure inequality. Yale University Press.

Paris, D. (2012). Culturally sustaining pedagogy: A needed change in stance, terminology, and practice. Educational Researcher, 41(3), 93-97. https://doi. org/10.3102/0013189X12441244

Peguero, A. A., \& Bondy, J. M. (2011). Immigration and students' relationship with teachers. Education and Urban Society, 43(2), 165-183. https://doi. org/10.1177/0013124510380233

Pollack, M. (2004). Colormute: Race talk dilemmas in an American school. Princeton University Press.

Santa Ana, O. (2002). Brown tide rising: Metaphors of Latinos in contemporary American public discourse. University of Texas Press.

Santau, A. O., Maerten-Rivera, J. L., \& Huggins, A. C. (2011). Science achievement of English language learners in urban elementary schools: Fourth-grade student achievement results from a professional development intervention. Science Education, 95(5), 771-793. https://doi.org/10.1002/sce.20443

Shalaby, C. (2017). Troublemakers: Lessons in freedom from young children at school. The New Press.

Simpson, L. B. (2017). As we have always done: Indigenous freedom through radical resistance. University of Minnesota Press.

Valencia, R. R. (2010). Dismantling contemporary deficit thinking: Educational thought and practice. Routledge. 
Viesca, K. M., Hammer, S., Alisaari, J., Routarinne, S., Teemant, A., Perumal, R., Flynn, N., \& Aquah, E. O. (2019, April 5-9). Quality content teaching for multilingual students: An international examination of instructional practices in four nations [Paper presentation]. 2019 American Educational Researchers Association Annual Meeting. Toronto, Canada.

Villegas, A. M., \& Lucas, T. (2007, March). The culturally responsive teacher. Educational Leadership, 64(6), 28-33.

Yosso, T. J. (2005). Whose culture has capital? A critical race theory discussion of community cultural wealth. Race, Ethnicity, and Education, 8(1), 69-91. https://doi.org/10.1080/1361332052000341006

Yosso, T. J. (2006). Critical race counterstories along the Chicana/Chicano educational pipeline. Routledge.

Zavarzadeh, M. (1992). Theory as resistance. In M. Kecht (Ed.), Pedagogy is politics: Literary theory and critical teaching (pp. 25-47). University of Illinois Press. 